\title{
Teaching mathematics at mexican elementary schools
}

\section{Ensino da matemática nas escolas primárias mexicanas}

DOI: $10.46932 / \mathrm{sfjdv2n5-008}$

Received in: Jun 1st, 2021

Accepted in: Sep 30th, 2021

\author{
Edith Arévalo Vázquez \\ Doctora \\ Escuela Normal Miguel F. Martínez \\ Av. Constitución s/n Col. Centro Nuevo León, México \\ E-mail: edith.arevalo@enmfm.edu.mx \\ Hilda Alicia Guzmán Elizondo \\ Maestra \\ Escuela Normal Miguel F. Martínez \\ Av. Constitución s/n Col. Centro Nuevo León, México \\ E-mail: hilda.guzman@enmfm.edu.mx \\ Elvira Alicia Sánchez Díaz \\ Maestra \\ Escuela Normal Miguel F. Martínez \\ Av. Constitución s/n Col. Centro Nuevo León, México \\ E-mail: elvira.sanchez@enmfm.edu.mx
}

\begin{abstract}
The present study offers results about the ways of teaching mathematics in groups of fifth and sixth grade of public elementary schools in Mexico, located in the state of Nuevo León. The objective was to assess the practices of 70 elementary school teachers, in accordance with the application of the didactic approach suggested from the current syllabus (2011) in mathematics classes. It is a study of descriptive scope. For the information retrieval, an observation guide was used, based on the current curriculum for basic education. Teaching strategies, forms of class organization, classroom organization, use of teaching materials, assessment tools and textbook, among others, were the categories taken into account. The results show that despite the implementation of the current curriculum, most educators continue to use teaching strategies that are far from the suggested didactic recommendations. The textbook is the resource used par excellence and the forms of classroom organization are preferably by working individually and as a group. Those practices keep showing not very encouraging results at national and international levels.
\end{abstract}

\section{RESUMEN}

El presente estudio ofrece resultados sobre las formas de enseñar matemáticas en grupos de quinto y sexto grado de escuelas primarias públicas de México, ubicadas en el estado de Nuevo León. El objetivo fue evaluar las prácticas de 70 profesores de primaria, de acuerdo con la aplicación del enfoque didáctico sugerido desde el programa de estudios vigente (2011) en las clases de matemáticas. Es un estudio de alcance descriptivo. Para la recuperación de la información se utilizó una guía de observación, basada en el plan de estudios vigente para la educación básica. Las estrategias de enseñanza, las formas de organización de la clase, la organización del aula, el uso de materiales didácticos, los instrumentos de evaluación y el libro de texto, entre otros, fueron las categorías que se tuvieron en cuenta. Los resultados muestran que, a pesar de la implementación del currículo vigente, la mayoría de los educadores sigue 
utilizando estrategias de enseñanza que se alejan de las recomendaciones didácticas sugeridas. El libro de texto es el recurso utilizado por excelencia y las formas de organización del aula son preferentemente el trabajo individual y el grupal. Estas prácticas siguen mostrando resultados poco alentadores a nivel nacional e internacional.

\section{THE TEACHING OF MATHEMATICS IN MEXICO}

The school's function is not only to teach children and young people what they do not know, but to contribute to develop the ability to learn how to learn. It means learning to think, to question causes and consequences, to control learning processes, to value what is learned and, above all, to encourage interest and motivation to continue learning throughout life (SEP, 2017).

In Mexico, the current curriculum for basic education (2011) lays its foundations in a constructivist understanding. The student is perceived as the center of the teaching-learning process and as the mainprotagonist in the construction of what it is learned (SEP, 2011). Also, a mathematical training that enables to face and solve problems in the day-to-day work through the acquisition of knowledge, skillsdevelopment and the encouragement of attitudes provided by this educational process is promoted.

From the didactic approach, it is expected to favor a mathematical education which necessarily impliesthe active participation of both the teacher and the students. Likewise, it is established as a priority action the approach of problematic situations so that the students solve them with their own resources;to discuss in groups, analyze their procedures and results in order to share their ideas and enrich themwith the classmates' opinions (SEP, 2011). In this sense, "the knowledge of rules, algorithms, formulasand definitions is only important to the extent that students can use them skillfully to solve problems and can rebuild them, in case of forgetting" (SEP, 2011, p. 66). It is also required to work in processesthat go from informal to conventional.

For the treatment of Mathematics in the classroom, it has been attempted to break with the classical teaching scheme, where the teacher is the owner of a body of finished knowledge that must be transmitted to the student and where he/she receives and reproduces them, to the extent of his/her possibilities. Under the current didactic approach, the teacher's job is to design and ease tasks in which the students develop their mathematical thinking, according to the expected learning suggested on the curriculum (Cantoral, 2007).

In this sense, it is not about the teacher looking for the simplest and most enjoyable explanations to share with the students; his/her task involves analyzing and proposing interesting problems, properly structured, so that students use what they know and advance in the development of mathematical techniques and reasoning increasingly effective. This role is the essence of teaching work as an 
education professional in the teaching of school mathematics.

Likewise, the teacher is implied, among other actions, to (SEP, 2011; SEP, 2017):

- Have disciplinary and pedagogical knowledge about mathematics.

- Organize classroom work through various forms of social organization of the class.

- Generate authentic learning contexts where students use and develop their mathematical thinking.

-Plan and implement meaningful teaching strategies for the students.

-Promote reflection through questions and counterexamples.

-Allow the students to solve problems using their own procedures.

-Promote and coordinate sharing with the intention of analyzing, comparing and obtaining conclusions together that favor the social construction of knowledge (socialization of learning).

- Link mathematical contents with those of other subjects.

-Encourage students to have positive and critical attitudes towards the study of mathematics.

These actions are expected to favor the development of the four mathematical competences proposedfor basic education: solve problems autonomously; communicate mathematical information; validate procedures and results; and manage techniques efficiently (SEP, 2017).

Based on this proposal, "both the students and the teacher face new challenges that demand different attitudes towards mathematical knowledge and different ideas about what teaching and learning meansin this subject" (SEP, 2011, p. 66). The great challenge is to learn to think differently, modifying the pattern of knowledge reproduction; in order to replace it with another that leads to its progressive construction. The challenge is greater since in the country there are more than 14.2 million students of primary education in 98,000 schools; assisted by about 600,000 teachers (SEP, 2017) representing the largest educational level in Mexico.

\section{METHODOLOGY}

This research is descriptive. In the search for information, routes were generated, applying aninstrument that reports the use of the qualitative approach. This kind of studies is useful to understand social reality, in which the natural context and social sense are observed, as well as the way in which it affects individuals (Martínez, 2007). It is learned about the phenomena that occur around it and their cause and effect relationships, in order to interfere with them or use this knowledge to improve processes.

For the data collection, qualitative observation was carried out in natural environments, with the 
support of an observation guide for the assessment of teachers' instruction. The analysis made possibleto know about how teachers organized and developed their teaching work in the classroom. The observation guide was formed by structured categories according to the review of the pedagogical and methodological foundations to address the Mathematics subject in fifth and sixth grades of elementary school, which are expressed in the normative documents edited by the national Ministry of Public Education (Secretaría de Educación Pública). Among the indicators to be assessed are: strategies or resources used by educators for teaching; use of teaching materials; forms of social organization of the class; contextualization of mathematical contents; socialization of expected learning; linking orrelation of Mathematics topics with other educational fields or subjects; assessment instruments, role of the teachers during Mathematics classes (Arévalo, 2017). For its treatment and analysis, the information was concentrated in data matrices (professor/categories), making records in each of the cells regarding what was identified in the observations.

The sample for the research was made up of 70 professors located in fifth and sixth grade of public elementary schools of three municipalities in the state of Nuevo León. The teachers have a career of between 10 and 24 years in the educational system. The schools searched belonged to different contexts and population, as well as different working conditions. The number of students per group in the institutions ranged from 28 to 40 students. To guarantee the anonymity and confidentiality of the participants, everyone was identified under the heading of professor, avoiding mentioning their gender.

\section{RESULTS}

In summary, we present preliminary results, highlighting those that we value, to allow the reader to know the status about the relevant aspects regarding the teaching of mathematics by elementary school teachers, according to the didactic approach suggested in the current curriculum in Mexico.

Relating to the teachers' instruction organization

Concerning the strategies used for teaching mathematical content, in some cases the teachers workedwith more than one. The results show that $46 \%$ of the teachers worked exclusively with the exercises suggested in the textbooks, called Mathematical Challenges, summed up in reading the problematic situations and answering them sometimes individually and other times in group. These teachers also worked with activities in which the students had to solve problems in the notebook used for the subject.The requested products were pieces of work that meet the logic of knowledge. They were able to write definitions; register examples and counterexamples; make algorithm mechanizations for addition, subtraction, multiplication, division; solve problems with fractions; draw figures; find perimeter measures, as well as calculate areas and volumes; among others. 
Thirty percent of the teachers addressed the contents based on the answer of worksheets that included problem solving; most of these cases were solved individually. It was identified that the notebooks andworksheets included productions and activities that led to reproduction and recording, in some cases, what the teacher dictated or copying what was written on the board. This type of practice generates a dependence on the student towards the teacher regarding the construction and acquisition of learning (Frade, 2015), limiting the students' ability to think, infer, provide their own solutions, contrast procedures, identify what they know and what they need to learn, as it would be expected from the pedagogical approach of the study programs, for the treatment of mathematics in fifth and sixth gradesof elementary education (SEP, 2011).

Only $12 \%$ of the teachers included didactic games to the Mathematics class. Among the games used are bingo of numbers, puzzles, numerical roulette, dominoes, and convenience store. Without a doubt,playing is an important part of children's lives and should be used to promote learning. It helps the development of mathematical competences, since through them, students discover abilities, skills to organize, propose and represent solutions to the challenges they face (SEP, 2017). It should not be forgotten that when using a game as a learning activity, the purpose for the student will be to win; however, the real purpose would be to learn a certain mathematical knowledge.

Likewise, $10 \%$ incorporated a tutorial or didactic video and $2 \%$ used some technological application for the treatment of content in class (Figure 1); although, from the didactic recommendations, the teacher is suggested to select and use diverse educational resources that allow students to practice theirmathematical thinking. As already mentioned, one of the teacher's tasks is to create the appropriate conditions for the students to build meaningful learning; that is, knowledge that is available to be usedadequately and flexibly in diverse situations.

Figure 1. Resources to teach Mathematics.

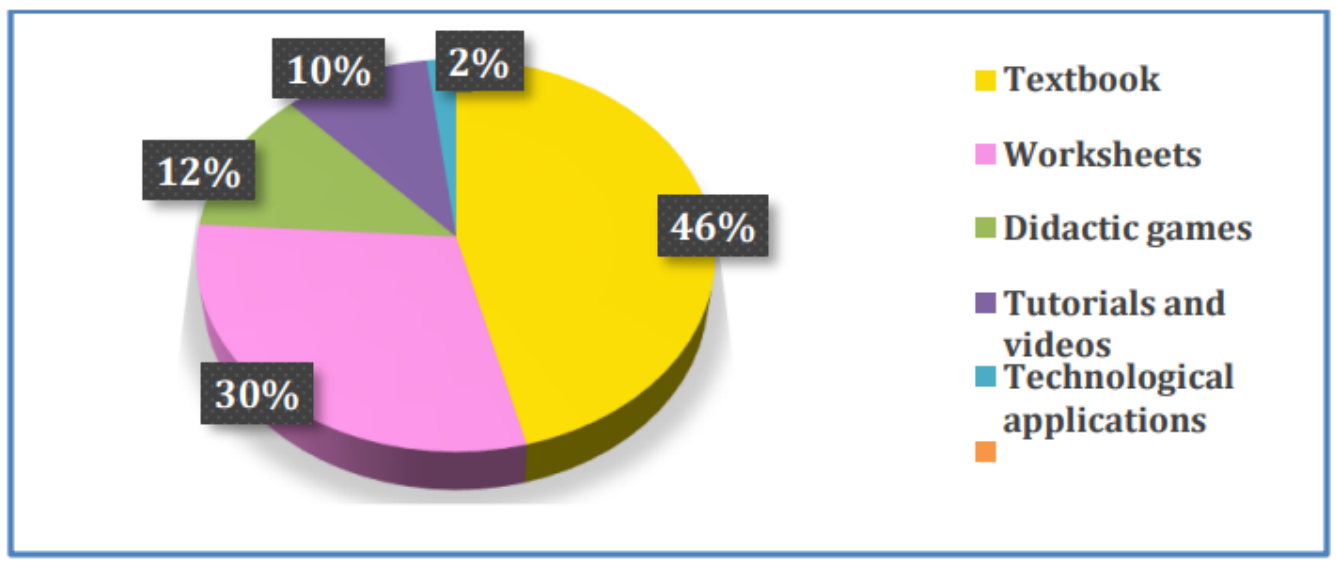

In reference to the didactic materials incorporated during the development of the class, $21 \%$ 
worked with numerical series, $18 \%$ used concrete material for counting such as cards and other manageable objects (Figure 2), 12\% of the teachers included interactive games, $6 \%$ the tangram, $2 \%$ bingo of numbers, puzzles and abacus. The rest of the teachers did not incorporate any type of material, since they used the textbook as a guide for the classroom work.

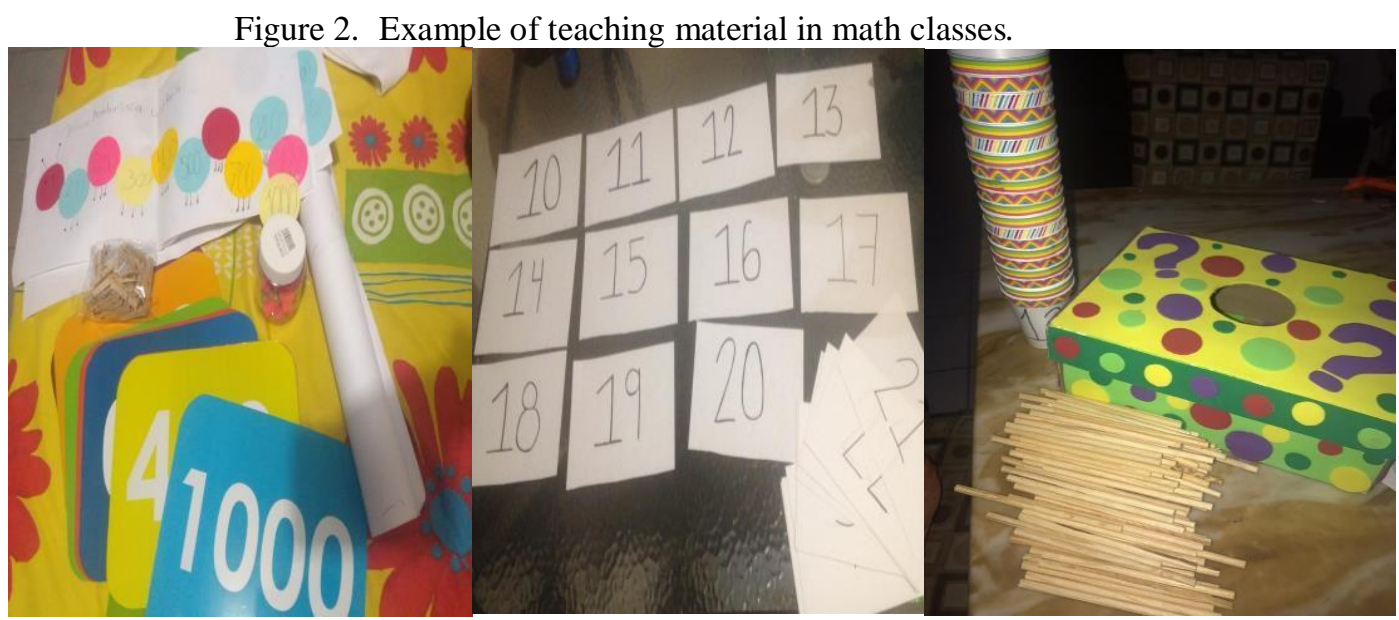

Regarding the forms of social organization of the class, $41 \%$ of the teachers organized the students individually and in groups during the class; $23 \%$ always worked individually; $20 \%$ combined individual and teamwork; $13 \%$ always worked in groups during class; and only 3\% organized the students to work in teams during the development of the activities. In this regard, recent didactic approaches refer within their guidelines that the experience of autonomous/individual work, work in collaborative groups and discussion, as well as group reflection and argumentation generate learning environments suitable for the development of mathematical skills (SEP, 2011); making clear the relevance of working with diverse forms of social organization in class.

Thirty-one percent of the teachers contextualized the content discussed during the class. Among the daily life situations that teachers included to place in context the mathematical contents are: food distribution, surveys, measurements of objects, voting, news that occurred on the previous day, purchases in the supermarket, use of currency in force, newspaper articles, items in supermarket brochures. These teachers searched for contextualization that invited students to get involved in their learning, using situations of daily life in which they are immersed. For the treatment of mathematical contents, it is necessary to consider different situations that allow laying out problems in which the resolution requires its use.

The rest of the teachers did not consider necessary the contextualization of learning, discarding situations in the daily life of their students, although it is suggested from the didactic approach that the student should look at mathematics a little beyond the mathematical contents, and explore the 
knowledge in use in their daily work (SEP, 2011). These professors showed examples of problems or situations "created" from the classroom, without having the same level of complexity as the problems they have in day-to-day life. It is common to identify that students are faced with fictitious problematic situations that are unrelated to other aspects relevant to them, which causes a deep disinterest in the mathematical contents treated in school (Cantoral, 2007). Given this scenario, it is necessary to reflecton the type of problematic situations and activities that should be proposed to the group.

Only $35 \%$ of the teachers offered spaces during the class for students to share their procedures or results; although it is established in the curriculum that the teacher must analyze the students work on mathematical tasks, both simple and complex, as well as the ways of understanding the construction process of mathematical concepts and processes in order to figure out how they develop their mathematical thinking (SEP, 2011). Of this percentage, 38\% opened the space during the treatment of mathematical content and $62 \%$ during class closing.

Under this scenario, students cannot be expectedto learn to make arguments if the responsibility is not delegated to them to find out whether the procedures or results, their own and those of others, are correct or incorrect. Working alone solving problems, without explaining or substantiating mathematically, is insufficient. What is expected is thatafter solving the problems, the procedures performed that led to a solution are shared and explained. This is one of the most difficult moments of the teacher, since, based on his/her experience, he/she must select the convenient moment to intervene; in such a way that his/her participation does not replace the student's work or hinder their learning process.

On the other hand, $94 \%$ of the teachers did not relate the contents of Mathematics to topics from othersubjects that are part of the school curriculum in these grades. Six percent of the teachers who actuallylinked topics related them to the Spanish and Geography subjects. In this regard, it should be noted that when knowledge is structured in a fragmented and unrelated way, the student can hardly connecthis/ her knowledge to other areas. The suggestion from the didactic approach is to try to link, wheneverpossible, the contents of different subjects. For example, those of Mathematics have themes in common with those of Natural Sciences and Geography, especially concerning the elaboration and interpretation of graphs, the use of numbers and measurement, among others (SEP, 2011).

Regarding the evaluation instruments used, $61 \%$ of the teachers valued the students' learning based onthe productions in the notebooks and the textbook exercises. The teachers considered the result withoutstopping to observe the processes carried out by the students to reach a solution. This action makes itimpossible to identify what "mistakes" they made during the process, in order to intervene in a timelymanner and help them in the construction of new mathematical learning. 
Twenty percent worked with checklists, only $16 \%$ used rubrics and $3 \%$ the work evidence portfolio. (Figure 3) About this, it is necessary to remember that the evaluation with a formative approach mustbe understood as a process that allows to know the way in which the students organize, structure and use their learning in certain contexts to solve problems of different levels of complexity and diverse nature (SEP, 2012).

Figure 3. Instruments to assess learning.

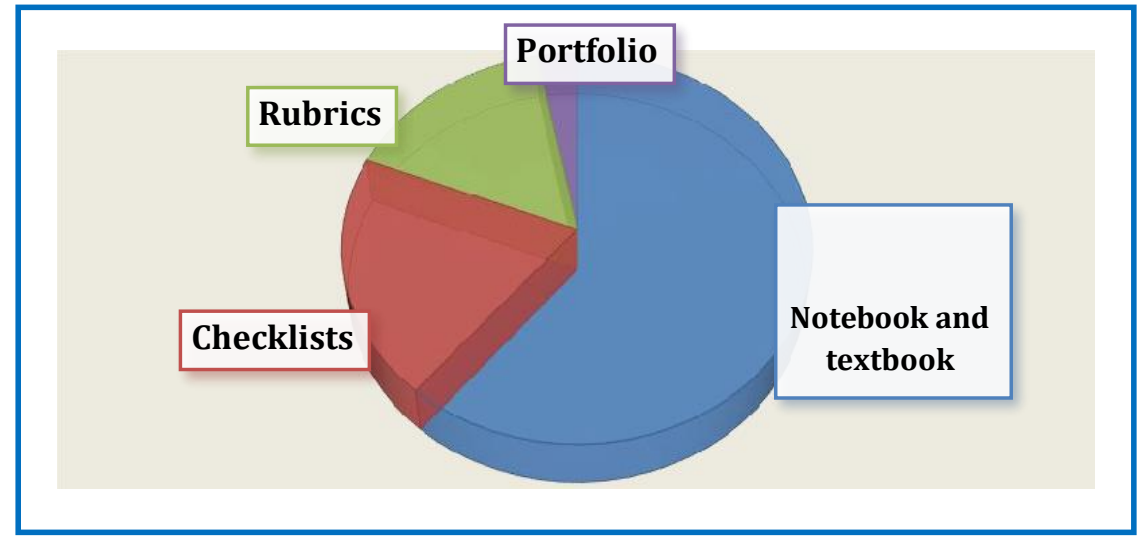

In this sense, evaluating is not about identifying the presence or absence of information to determine a grade; it is also necessary to have knowledge mobilization, skills and attitudes that can be assessed

through grading tools in which the evaluation indicators are fully defined. Understanding that indicators are "those quality criteria and requirement that must be evidenced when executing any competency... must account for the presence or absence of the competency that is expected to be observed in the execution" (Frola \& Velázquez, 2015, p. 16). Among the recommended grading tools for assessing mathematical competencies are the checklist, estimate scale and rubric scale.

It is concluded that the central role of $69 \%$ of the teachers was focused on being an instructor and exponent of contents, $15 \%$ as a learning guide and/or mediator, $16 \%$ was an exponent at certain moments or a learning mediator at some others (Figure 4). 
Figure 4. Role of the teacher in Mathematics classes.

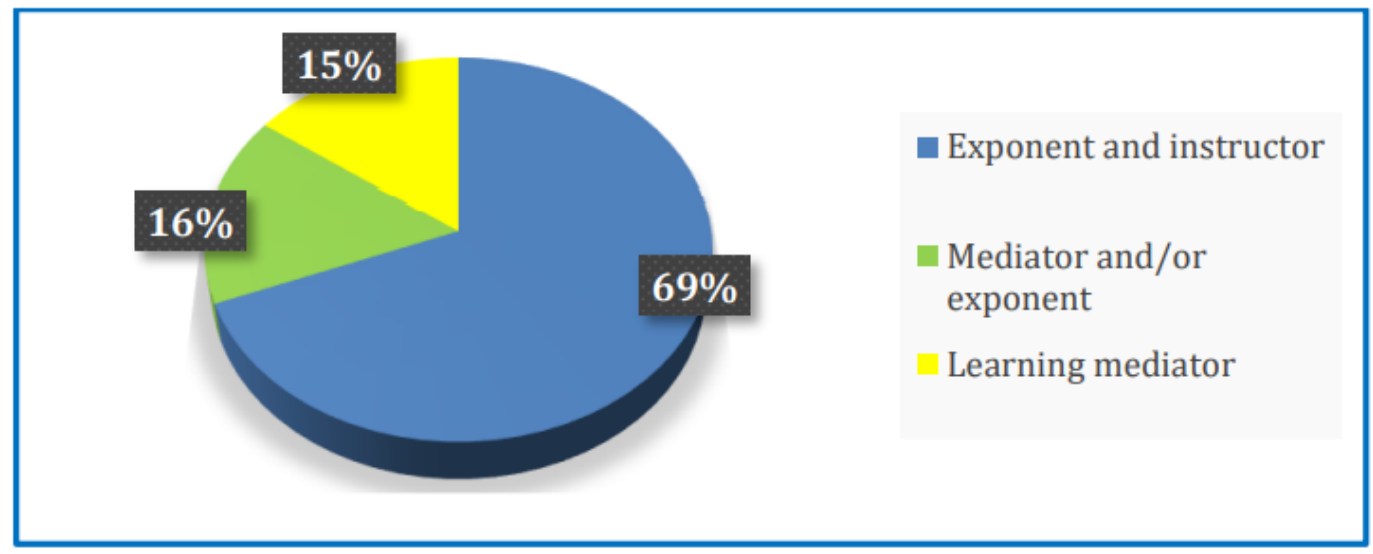

Under these circumstances, it is necessary to remember that teachers fulfill an essential function in thelearning of their students, since he/she should not be limited to be a transmitter of knowledge. From the current curriculum, he/she is conceived as a professional mediator who plays a fundamental role in the educational field. The teacher's work is vital for students to learn and overcome even the backwardness obstacles they face. He/she must also have tools to transform students' mistakes into true learning opportunities; helping them to identify both the error and its origin. In summary, the teacher will have to design and propose successful experiences that contribute to the construction of mathematical knowledge.

\section{CONCLUSION}

Despite the implementation of the 2011 curriculum, which highlights a constructivist approach and the student as the center of the teaching-learning process, it is identified in the study that $69 \%$ of the 70 participating teachers keep an influence towards didactic conceptions in which instructional teaching is a priority. The treatment of school mathematics content in most of these teachers was characterized by following rules and procedures for solving problems, the routine practice of exercisesrather than learning situations, and the use of textbooks, individual work, and decontextualization of the contents. On the other hand, the evaluation, in the majority, was adjusted to checking the tasks made in notebooks and textbooks.

The implementation of teaching strategies that favor the achievement of the expected learning proposed on the curriculum is urgently needed. The suggested didactic approach promotes the socialization of knowledge among students, favoring social learning, fact that was only identified in $35 \%$ of the teachers. Mathematical contents are not generated in isolation, it is necessary to establish a link between topics of the diverse disciplines or areas of knowledge; if the contents are seen in parts,they will continue to make no sense to the students. 
Undoubtedly, the experiences students live when studying mathematics in school can result in interest or rejection, creativity to find solutions or passivity to receive information and reproduce patterns. Education should not be static; it must evolve and respond to the characteristics of the society in whichit is inserted. When education no longer responds to these needs, students do not find meaning in whatthey learn: as they cannot link it with their reality and context, they lose motivation and interest, whichbecomes one of the main causes of backwardness and dropout.

The considerations mentioned above confirm the need to educate the new generations based on the development of competencies, so that it is not only expected that they "know a lot"; but they can be competitive because they have acquired the ability to think and reflect for designing and using their own strategies which allow them to solve problems and be able to join a globalized and changing life.If different results are sought in the Mathematics subject, it is necessary to assume a constructivist andmore accurate position to the academic needs of the students in Mexico. 


\section{REFERENCES}

Arévalo, E. (julio, 2017). La enseñanza de las matemáticas en un grupo de primer grado de educación primaria, desde un contexto comunicativo. VIII Congreso Iberoamericano de Educación Matemática. Madrid, España. Recuperado el 30 de julio de 2017 de http://www.cibem.org/index.php/es/programa/libro-de-actas.

Frade, L. (2015). Desafíos a superar para desarrollar competencias en el aula. México: Grupo Editorial Patria.

Cantoral, R. (2007). Desarrollo del Pensamiento Matemático. México: Editorial Trillas.

Frola, P. \& Velázquez, J. (2015). Estrategias de aprendizaje y rúbricas de evaluación. México: Frovel Educación.

Martínez, R. (2007). La Investigación en la Práctica Educativa: Guía Metodológica de Investigación para el Diagnóstico y Evaluación de los Centros Escolares. Madrid: (CIDE).

Secretaría de Educación Pública (2011). Programas de Estudio 2011. Guía para el Maestro. Educación Básica Primaria Quinto grado. México: SEP.

Secretaría de Educación Pública. (2012). El enfoque formativo de la evaluación. Serie: Herramientas para la evaluaciónen Educación Básica. México: SEP.

Secretaría de Educación Pública. (2017). Aprendizajes Clave para la Educación Integral. Educación Primaria $1^{\circ}$. Grado.Plan y programas de estudios, orientaciones didácticas y sugerencias de evaluación. México: SEP. 